\author{
JOURNAL OF MARINE RESEARCH AND TECHNOLOGY \\ journal homepage: https://ojs.unud.ac.id/index.php/JMRT \\ ISSN: $2621-0096$ (electronic); $2621-0088$ (print)
}

\title{
Struktur Vegetasi Mangrove berdasarkan Karakteristik Substrat di Pantai Karang Sewu, Gilimanuk Bali
}

\author{
Pande Komang Egar Prihandana ${ }^{\mathrm{a}}$, I Dewa Nyoman Nurweda Putra ${ }^{\mathrm{a}^{*}}$, and Gede Surya Indrawan ${ }^{\mathrm{a}}$ \\ ${ }^{a}$ Program Studi Ilmu Kelautan, Fakultas Kelautan dan Perikanan, Universitas Udayana, Bali, Indonesia \\ *Corresponding author, email: nurweda14@unud.ac.id
}

\section{ARTICLE INFO}

\section{Article history:}

Received: August $13^{\text {th }} 2020$

Received in revised form: September $28^{\text {th }} 2020$

Accepted: November $12^{\text {th }} 2020$

Available online: February $28^{\text {th }} 2021$

Keywords:

Organic Ingridients

Mangrove

Substrates

Vegetation Structure

\section{ABSTRACT}

\begin{abstract}
Karang Sewu Beach is one of the areas in the West Bali National Park (TNBB) which has a natural mangrove ecosystem. One of parameters affecting mangrove growth is substrate. This research aims to determine the vegetation structure, substrate characteristics, and different vegetation groups of mangroves based on its substrate characteristics in Karang Sewu Beach. This study collected the data on vegetation structure using a plotted line method with $2 \times 2,5 \times 5$, $10 \times 10$ and 20x20 meters transects. Substrate texture was analyzed using a pipette method while total organic material was analyzed using the Loss on Ignition (LOI) method. Mangrove vegetation was categorized based on substrate characteristics using the descriptive quantitative method. Results showed there were nine species of mangrove found in Karang Sewu Beach, namely Ceriops tagal, Sonneratia alba, S. caseolaris, Rhizophora apiculata, $R$. mucronata, $R$. stylosa, $R$. lamarckii, Lumnitzera racemosa, and Avicennia marina. INP in the first station was dominated by $R$. apiculata for tree levels $(152,88 \%)$, pole $(174,24 \%)$, sapling $(139,04 \%)$, and seedling $(111,48 \%)$. R. lamarckii dominated the second station with a tree level value of 226,94 $\%$ while $C$. tagal dominated for pole level $(220,82 \%)$, sapling $(243,65 \%)$, and seedling $(182,94$ $\%)$. INP in the third stasion was dominated by $C$. tagal for pole level $(103,68 \%)$, sapling $(98,77$ $\%)$ and seedling $(95,51 \%)$. Mangrove substrate in Karang Sewu Beach was characterized as having a sand like texture, dusty loam, sandy loam, loamy sand, and sandy clay with moderate organic matter $(2.44 \%)$ to low $(0.79 \%)$. Mangrove vegetation grouping based on substrate characteristics in Karang Sewu Beach was different in general. A. marina is found in the middle zone, where this species is usually found in the front zone.
\end{abstract}

2021 JMRT. All rights reserved.

\section{Pendahuluan}

Mangrove merupakan salah satu komunitas tumbuhan yang tumbuh di sepanjang pantai, estuari atau muara sungai pada daerah tropis (Mullet et al., 2014). Kata Mangrove berasal dari kata "mangue atau mangal" dari bahasa Portugis dan "grove" dari bahasa Inggris yang secara umum berarti formasi hutan yang tumbuh pada kondisi substrat anaerobik dan masih terpengaruh oleh adanya pasang surut air laut (Saenger et al., 1983). Ekosistem mangrove berfungsi sebagai kunci utama penyedia makanan bagi organisme yang tinggal di sekitar ekosistem tersebut seperti ikan, kepiting, udang, burung, mamalia, serta memiliki manfaat ekologis dan ekonomis bagi masyarakat pesisir (Davies and Claridge, 1993).

Pemanfaatan mangrove dibedakan menjadi dua yaitu berdasarkan tingkat komponen ekosistem secara keseluruhan dengan menjadikan ekosistem mangrove sebagai lahan tambak, lahan pertanian, lahan kolam garam, serta lahan pariwisata, dan berdasarkan ekosistem mangrove sebagai principal biotic component menjadi bahan makanan, kayu bangunan, kayu bakar, dan obat-obatan (Kusmana et al., 2003). Berbagai pemanfaatan ekosistem mangrove harus memperhatikan kelestarian mangrove serta daya dukung yang ada, apabila pemanfaatan mangrove dilakukan secara berlebihan maka akan berdampak buruk bagi kelestarian mangrove itu sendiri (Darmadi et al., 2012). Murray (2011) menyatakan bahwa kerusakan ekosistem mangrove disebabkan oleh adanya alih fungsi lahan di seluruh dunia mencapai 430.000 sampai 980.000 hektar. Upaya untuk mengoptimalkan fungsi dan manfaat ekosistem mangrove agar tidak terjadi eksploitasi perlu dilakukan kegiatan konservasi (Pendleton et al., 2012). Salah satu upaya kegiatan konservasi adalah pemulihan ekosistem mangrove, dimana pemulihan yang dilakukan harus tepat guna, seperti penanaman yang dilakukan harus memperhatikan kesesuaian vegetasi terhadap substrat (Setiawan, 2013).

Substrat mangrove merupakan sedimen yang berasal dari sungai atau endapan karbonat laut yang memiliki salinitas, oksigen yang rendah, banyak mengandung bahan organik dan selalu basah (Soerianegara, 1971). Vegetasi mangrove pada dasarnya dapat tumbuh baik pada substrat lumpur, namun dapat ditemukan juga pada substrat pasir dan batu karang (Basyuni, 2014). Karakteristik substrat yang baik dapat menentukan 
distribusi vegetasi mangrove untuk tumbuh dan berkembang (Davies and Claridge, 1993).

Pantai Karang Sewu terletak di Kelurahan Gilimanuk, Kecamatan Melaya, Kabupaten Jembrana, Bali merupakan salah satu bagian dari kawasan Taman Nasional Bali Barat (TNBB) yang memiliki tiga ekosistem pesisir salah satunya adalah mangrove. Masyarakat di kawasan Pantai Karang Sewu yang dibina oleh TNBB telah melakukan upaya pemulihan ekosistem mangrove dengan melaksanakan kegiatan pembibitan dan penanaman mangrove sejak tahun 2018. Hal ini bertujuan untuk mempertahankan kelestarian ekosistem mangrove di kawasan tersebut, namun hingga saat ini ketersediaan data mengenai kesesuaian vegetasi berdasarkan karakteristik substrat belum ada. Berdasarkan permasalahan tersebut, maka diperlukan penelitian mengenai kondisi struktur vegetasi mangrove berdasarkan karakteristik substrat sehingga dalam melakukan pemulihan khususnya penanaman bibit mangrove dapat disesuaikan dengan kesesuaian vegetasi berdasarkan karakteristik substrat.

\section{Metode}

\subsection{Waktu dan Tempat}

Penelitian ini dilasanakan pada bulan Januari hingga Mei 2020. Lokasi penelitian dilakukan di Pantai Karang Sewu, Kelurahan Gilimanuk, Kecamatan Melaya, Kabupaten Jembrana, Bali yang dibagi menjadi tiga stasiun (Gambar 1). Analisis tekstur substrat dan bahan organik total dilakukan di Laboratorium Tanah Fakultas Pertanian Universitas Udayana. Metode penentuan stasiun pengamatan menggunakan metode purposive sampling berdasarkan keberadaan vegetasi mangrove di Pantai Karang Sewu. Stasiun 1 ( $8^{\circ} 10^{\prime} 34.96 " S$ dan $\left.114^{\circ} 26^{\prime} 32.20 " E\right)$ berada pada kawasan mangrove Pantai Karang Sewu di sisi barat daya Teluk Gilimanuk dan terletak lebih jauh dari bibir teluk, sedangkan Stasiun $2\left(8^{\circ} 10^{\prime} 14.04^{\prime \prime S}\right.$ dan $\left.114^{\circ} 26^{\prime} 36.34 " E\right)$ dan Stasiun 3 $\left(8^{\circ} 10^{\prime} 14.04^{\prime \prime S}\right.$ dan $\left.114^{\circ} 26^{\prime} 36.34^{\prime \prime E}\right)$ berada pada kawasan mangrove Pantai Karang Sewu di sisi barat Teluk Gilimanuk dan terletak lebih dekat dengan bibir teluk.

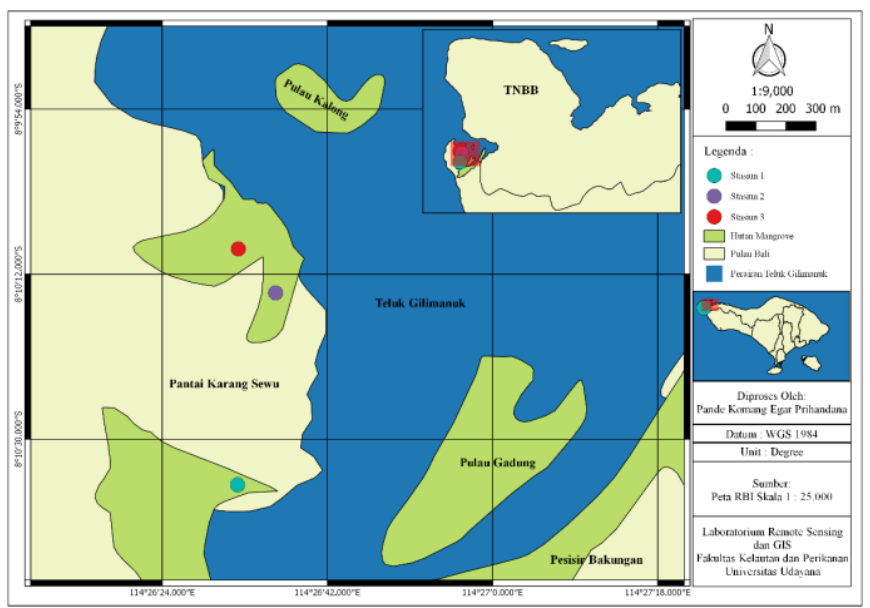

Gambar 1. Peta lokasi penelitian

\subsection{Pengumpulan Data}

Pengambilan data vegetasi mangrove mengikuti Kusmana (2017) menggunakan metode garis berplot pada saat pasang menuju surut. Setiap stasiun digunakan dua garis transek yang ditarik mulai dari vegetasi terdepan (dekat dengan laut) menuju arah daratan secara tegak lurus terhadap garis pantai dengan jarak antar garis transek sepanjang $100 \mathrm{~m}$. Jumlah plot yang digunakan sebanyak tiga plot pada masing-masing garis transek dengan ukuran yang bertingkat (kuadrat) yaitu $2 \times 2 \mathrm{~m}$ untuk tingkat semai (tinggi tegakan $<1,5 \mathrm{~m}$ ), 5x5 $\mathrm{m}$ untuk tingkat pancang (tinggi $>$
1,5 $\mathrm{m}$ dan dan diameter batang $<10 \mathrm{~cm}), 10 \times 10 \mathrm{~m}$ untuk tingkat tiang (diameter batang 10-20 cm), dan 20x20 m untuk tingkat pohon (diameter batang $\geq 20 \mathrm{~cm}$ ) dengan jarak antar plot sepanjang $10 \mathrm{~m}$.

Pengambilan sampel substrat dilakukan pada setiap plot berukuran 20x20 meter. Setiap plot dilakukan pengulangan sebanyak lima kali menggunakan pipa PVC (Polivinil Klorida) berdiameter $10 \mathrm{~cm}$ yang ditancapkan sampai kedalaman $15 \mathrm{~cm}$ dengan berat akumulasi tiap plot 1000 gram kemudian disimpan ke dalam kantong plastik ziplock untuk dianalisis lebih lanjut di dalam laboratorium (Indah et al., 2010).

Parameter lingkungan yang diukur dalam penelitian ini adalah $\mathrm{pH}$ substrat dan air yang diukur menggunakan $\mathrm{pH}$ meter, salinitas yang diukur menggunakan handrefractometer, serta suhu substrat dan air menggunakan termometer. Pengambilan data parameter lingkungan dilakukan pengulangan sebanyak lima kali pada setiap plot berukuran 20x20 meter saat pasang menuju surut. Data yang telah diukur pada setiap plot, kemudian dihitung untuk mendapatkan nilai rata-rata parameter lingkungan tiap stasiun.

\subsection{Analisis Data}

\subsubsection{Analisis Struktur Vegetasi Mangrove}

Data vegetasi mangrove yang telah dikumpulkan, kemudian dilakukan analisis yang mengacu pada Kusmana (2017), dimana setiap jenis vegetasi dihitung kerapatan (Di), kerapatan relatif (RDi), frekuensi (Fi), frekuensi relatif (RFi), dominansi (Ci), dan dominansi relatif (RCi). Selanjutnya, dihitung INP untuk menentukan kedudukan ekologis suatu jenis dalam komunitas dengan menjumlahkan ketiga parameter tersebut.

\subsubsection{Pengukuran Tekstur Substrat}

Pengukuran tekstur substrat mengikuti Lanuru (2011) dan Puja (2016) menggunakan metode pipet. Sampel sedimen yang telah dikumpulkan dikeringkan pada suhu udara (tidak dijemur dibawah sinar matahari), kemudian setiap sampel seberat 200 gram dibersihkan menggunakan aquades sebanyak $20 \mathrm{ml}$ untuk menghilangkan bahan organik terapung atau sampah dan ditambahkan Hidrogen Peroksida $\left(\mathrm{H}_{2} \mathrm{O}_{2}\right)$ sebanyak $15 \mathrm{ml}$ untuk mencegah substrat membentuk agregat lalu di diamkan selama 24 jam. Setelah didiamkan selama 24 jam, sampel dipanaskan menggunakan hot plate dengan suhu rendah sekitar $60{ }^{\circ} \mathrm{C}$ dan ditambahkan $\mathrm{H}_{2} \mathrm{O}_{2}$ sedikit demi sedikit hingga buih pada sampel berkurang. Setelah buih pada sampel berkurang, untuk menghilangkan sisa kandungan $\mathrm{H}_{2} \mathrm{O}_{2}$ ditambahkan air sebanyak $300 \mathrm{ml}$ kemudian panaskan kembali diatas hot plate selama $1 \mathrm{jam}$ dengan menaikkan suhu perlahan-lahan. Setelah dipanaskan selama 1 jam kemudian sampel didinginkan, lalu tambahkan Natrium Metaphosphat (Calgon) dan diamkan selama 24 jam agar sampel mengendap (deflokulasi).

Sampel yang mengendap kemudian disaring menggunakan ayakan dengan ukuran $0,053 \mathrm{~mm}$. Sampel substrat yang tersaring merupakan fraksi pasir yang selanjutnya dioven dengan suhu 105 ${ }^{0} \mathrm{C}$ selama $2 \times 24$ jam dan mencapai berat konstan (tidak terjadi perubahan berat saat ditimbang berulang-ulang). Sampel yang lolos atau tidak tersaring digunakan untuk menentukan fraksi debu dan liat. Setelah mencapai berat konstan, sampel diencerkan menggunakan aquades hingga menjadi $1000 \mathrm{ml}$, lalu diaduk hingga larutan homogen. Selanjutnya dilakukan pemipetan menggunakan pipet tetes sebanyak $20 \mathrm{ml}$. Hasil pemipetan dipindahkan ke cawan petri, kemudian ditimbang menggunakan timbangan analitik dan dilakukan perhitungan berat pada masingmasing sampel serta dilakukan perhitungan persentase masingmasing fraksi pada setiap plot, menggunakan rumus Wentworth (1922) sebagai berikut : 


$$
\begin{aligned}
& \% \text { Pasir }=\frac{\text { berat pasir }}{\sum \text { berat sampel }} \times 100 \% \\
& \% \text { Debu }=\frac{\text { berat debu }}{\sum \text { berat sampel }} \times 100 \% \\
& \% \text { Liat }=100-(\% \text { Pasir }+\% \text { Debu })
\end{aligned}
$$

Hasil analisis pemipetan kemudian dilakukan pengklasifikasian berdasarkan segitiga tekstur menurut Wentworth (1922).

\subsubsection{Pengukuran Bahan Organik Total}

Untuk mengetahui bahan organik pada substrat digunakan metode LOI (Loss on Ignition) dengan substrat seberat 5 gram ditempatkan pada wadah (cawan porselen), kemudian dikeringkan menggunakan oven dengan suhu $500{ }^{0} \mathrm{C}$ selama 5 jam (Heiri et al., 2001). Setelah dikeringkan, kadar bahan organik dihitung berdasarkan ketetapan Allen et al. (1974) sebagai berikut:

$$
\mathrm{BOT}=\frac{(\mathrm{Wt}-\mathrm{C})-(\mathrm{Wa}-\mathrm{C})}{\mathrm{Wt}-\mathrm{C}} \times 100 \%
$$

Dimana BOT merupakan Bahan Organik Total (\%); Wt merupakan berat total antara cawan dan sampel sebelum dibakar; C merupakan berat cawan (kosong); dan Wa merupakan berat total cawan dan sampel setelah dibakar.

\subsubsection{Pengelompokkan Vegetasi Mangrove berdasarkan Karakteristik Substrat}

Metode yang digunakan dalam menentukan pengelompokan vegetasi mangrove berdasarkan katakteristik substrat adalah metode deskriptif kuantitatif, dengan cara mengidentifikasi spesies mangrove yang tumbuh pada masing-masing karakteristik substrat yang diperoleh dari data hasil analisis struktur vegetasi dan karakteristik substrat di seluruh stasiun pengamatan.

\section{Hasil dan Pembahasan}

\subsection{Kondisi Lingkungan}

Berdasarkan pengukuran parameter lingkungan yang dilakukan di lokasi penelitian, hasil nilai parameter dapat dilihat sebagai berikut:

Tabel 1. Parameter Lingkungan

\begin{tabular}{cccccc}
\hline \multirow{2}{*}{ Stasiun } & \multicolumn{2}{c}{$\mathbf{p H}$} & \multicolumn{2}{c}{ Suhu $\left({ }^{\mathbf{0}} \mathbf{C}\right)$} & \multirow{2}{*}{ Salinitas $(\% \mathbf{\% 0})$} \\
\cline { 2 - 5 } & Air & Substrat & Air & Substrat & \\
\hline 1. & 6,5 & 6,6 & 30,5 & 30,5 & 34 \\
2. & 6,5 & 6,6 & 28,4 & 28,6 & 35,2 \\
3. & 6,9 & 6,9 & 30,9 & 31,2 & 34,8 \\
\hline
\end{tabular}

\subsubsection{Derajat Keasaman (pH)}

Kondisi pH air rata-rata pada seluruh stasiun berkisar 6,5 - 6,9 dan nilai $\mathrm{pH}$ substrat rata-rata yang didapat berkisar antara $6,6-$ 6,9 (Tabel 1). Baku mutu $\mathrm{pH}$ pada ekosistem mangrove berdasarkan Kepmen LH No. 51 Tahun 2004 adalah 7 - 8,5 sehingga nilai $\mathrm{pH}$ pada lokasi penelitian cenderung asam (MNLH, 2004). Kondisi pH yang cenderung asam di lokasi penelitian disebabkan oleh proses penguraian serasah mangrove yang menghasilkan kondisi asam mengalami kesetimbangan dengan kapasitas penyangga dari garam-garam karbonat dan bikarbonat laut yang bersifat basa (Ulqodry et al., 2010). Aktivitas dekomposer akan rendah apabila nilai $\mathrm{pH}$ cenderung asam. Rendahnya proses dekomposisi akan menyebabkan kurangnya kandungan hara dan mineral sehingga pertumbuhan mangrove akan terhambat (Poedjirahajoe et al., 2017).

Hal yang sama ditemukan di Wonomulyo, Sulawesi Barat dimana nilai $\mathrm{pH}$ air berkisar antara 6,04 - 6,54 (Saru, 2017). Hasil penelitian yang dilakukan Lestaru et al (2018) di Pulau Pannikiang, Sulawesi Selatan juga mendapatkan nilai $\mathrm{pH}$ substrat yang ditumbuhi oleh mangrove berkisar 6,5-6,6. Kondisi nilai $\mathrm{pH}$ yang berkisar antara $6-8,5$ masih dalam batas toleransi untuk pertumbuhan mangrove (Wijayanti, 2009).

\subsubsection{Suhu}

Kondisi suhu air dan substrat yang diperoleh dari pengukuran di lokasi penelitian sangat bervariasi dengan kisaran suhu air ratarata antara $28,4-30,9{ }^{\circ} \mathrm{C}$ dan suhu substrat rata-rata berkisar antara $28,6-31,2{ }^{\circ} \mathrm{C}$ (Tabel 1). Suhu air tertinggi terdapat pada Stasiun 3 yakni $30,9{ }^{\circ} \mathrm{C}$, sedangkan suhu air terendah terdapat pada Stasiun 2 yakni $28,4{ }^{\circ} \mathrm{C}$. Suhu substrat tertinggi dapat ditemukan pada Stasiun 3 yakni $31,2{ }^{\circ} \mathrm{C}$, sedangkan suhu terendah terdapat pada Stasiun 2 yakni $28,6{ }^{\circ} \mathrm{C}$.

Merujuk Kepmen baku mutu air laut untuk biota laut, suhu optimal ekosistem mangrove adalah $28-30{ }^{\circ} \mathrm{C}$, sehingga suhu ekosistem mangrove di Pantai Karang Sewu masih tergolong batas toleransi (MNLH, 2004). Suhu akan mempengaruhi produksi daun mangrove, suhu optimal untuk produksi daun Rhizophora sp., Ceriops sp. dan Lumnitzera sp. adalah $26-28$ ${ }^{0} \mathrm{C}$, dan Avicennia sp. tumbuh optimal pada suhu $18-20{ }^{0} \mathrm{C}$ (Alwidakdo et al., 2014). Hal yang sama ditemukan di Estuari Perancak, Bali dimana kondisi suhu pada daerah mangrove alami berkisar antara $29,08-30,5{ }^{\circ} \mathrm{C}$ (Susiana, 2015). Perbedaan suhu dapat disebabkan oleh kerapatan vegetasi mangrove, semakin rapat vegetasi mangrove maka suhu akan semakin rendah, karena cahaya matahari yang masuk ke ekosistem mangrove terhalangi oleh tutupan kanopi (Hambaran, 2014).

\subsubsection{Salinitas}

Nilai Salinitas berkisar antara $34-35,2 \%$ (Tabel 1). Nilai salinitas tertinggi terdapat pada Stasiun 2 yakni $35,2 \%$ sedangkan nilai salinitas terendah terdapat pada Stasiun 1 yakni $34 \%$. Berdasarkan Kepmen LH No. 51 Tahun 2004, salinitas pada ekosistem mangrove optimal sampai $34 \%$ sehingga salinitas di Pantai Karang Sewu masih tergolong batas toleransi (MNLH, 2004). Kondisi salinitas yang tinggi juga ditemukan di ekosistem mangrove Desa Teling Kecamatan Tombariri, dimana suhu pada zona Sonneratia sp. berkisar antara $33-35,5 \%$ (Kolinug et al., 2014).

Tingginya nilai salinitas di lokasi penelitian disebabkan oleh adanya pasang surut air laut dan tidak ditemukan aliran sungai, sehingga suplai air tawar ke ekosistem mangrove tidak tersedia (Zakaria, 2019). Salinitas yang tinggi tidak terlalu berdampak bagi vegetasi mangrove, bahkan pada kandungan salinitas yang ekstrem sekalipun mangrove mampu beradaptasi dengan mencegah masuknya garam melalui akar, memiliki sistem penyimpanan garam dan memiliki mekanisme ekskresi pengeluaran garam melalui daun (Martuti, 2013).

\subsection{Karakteristik Substrat}

Ekosistem mangrove di Pantai Karang Sewu secara keseluruhan terdapat lima tipe tekstur yaitu pasir, lempung berdebu, lempung berpasir, pasir berlempung dan lempung liat berpasir. Bahan organik total di lokasi penelitian termasuk dalam kategori sedang hingga sangat rendah (Tabel 2). 
Tabel 2. Hasil Pengukuran Tekstur Substrat

\begin{tabular}{|c|c|c|c|c|c|c|c|}
\hline \multirow{2}{*}{ St. } & \multirow{2}{*}{ Plt. } & \multicolumn{3}{|c|}{ Fraksi (\%) } & \multirow{2}{*}{$\begin{array}{c}\text { Tekstur } \\
\text { Substrat }\end{array}$} & \multirow{2}{*}{$\begin{array}{l}\text { BOT } \\
(\%)\end{array}$} & \multirow{2}{*}{$\begin{array}{l}\text { Kategori } \\
\text { BOT }\end{array}$} \\
\hline & & Pasir & Debu & Liat & & & \\
\hline \multirow[t]{6}{*}{1} & 1 & 88,71 & 9,32 & 1,98 & Pasir & 2,31 & $\mathrm{~S}$ \\
\hline & 2 & 21,54 & 74,51 & 3,95 & $\begin{array}{l}\text { Lempung } \\
\text { Berdebu }\end{array}$ & 2,44 & $S$ \\
\hline & 3 & 71,20 & 10,47 & 18,33 & $\begin{array}{l}\text { Lempung } \\
\text { Berpasir }\end{array}$ & 2,01 & $S$ \\
\hline & 4 & 85,31 & 3,24 & 11,45 & $\begin{array}{l}\text { Pasir } \\
\text { Berlempung }\end{array}$ & 1,61 & $\mathrm{R}$ \\
\hline & 5 & 87,06 & 1,85 & 11,09 & $\begin{array}{l}\text { Pasir } \\
\text { Berlempung }\end{array}$ & 2,01 & $S$ \\
\hline & 6 & 71,96 & 15,04 & 13,00 & $\begin{array}{l}\text { Lempung } \\
\text { Berpasir }\end{array}$ & 0,79 & SR \\
\hline \multirow[t]{6}{*}{2} & 1 & 80,32 & 8,26 & 11,42 & $\begin{array}{l}\text { Pasir } \\
\text { Berlempung }\end{array}$ & 1,19 & $\mathrm{R}$ \\
\hline & 2 & 66,60 & 10,11 & 23,30 & $\begin{array}{l}\text { Lempung } \\
\text { Liat Berpasir }\end{array}$ & 1,20 & $\mathrm{R}$ \\
\hline & 3 & 76,24 & 9,01 & 14,76 & $\begin{array}{l}\text { Pasir } \\
\text { Berlempung }\end{array}$ & 1,25 & $\mathrm{R}$ \\
\hline & 4 & 80,00 & 8,50 & 11,50 & $\begin{array}{l}\text { Pasir } \\
\text { Berlempung }\end{array}$ & 1,19 & $\mathrm{R}$ \\
\hline & 5 & 80,46 & 7,82 & 11,73 & $\begin{array}{l}\text { Pasir } \\
\text { Berlempung }\end{array}$ & 1,21 & $\mathrm{R}$ \\
\hline & 6 & 83,82 & 6,62 & 9,56 & $\begin{array}{l}\text { Pasir } \\
\text { Berlempung }\end{array}$ & 1,19 & $\mathrm{R}$ \\
\hline \multirow[t]{6}{*}{3} & 1 & 69,26 & 13,20 & 17,54 & $\begin{array}{l}\text { Lempung } \\
\text { Berpasir }\end{array}$ & 0,79 & SR \\
\hline & 2 & 82,45 & 8,78 & 8,78 & $\begin{array}{l}\text { Pasir } \\
\text { Berlempung }\end{array}$ & 0,80 & SR \\
\hline & 3 & 70,54 & 12,24 & 17,22 & $\begin{array}{l}\text { Lempung } \\
\text { Berpasir }\end{array}$ & 0,79 & SR \\
\hline & 4 & 83,45 & 4,56 & 11,99 & $\begin{array}{l}\text { Pasir } \\
\text { Berlempung }\end{array}$ & 1,19 & $\mathrm{R}$ \\
\hline & 5 & 81,82 & 6,14 & 12,04 & $\begin{array}{l}\text { Pasir } \\
\text { Berlempung }\end{array}$ & 1,61 & $\mathrm{R}$ \\
\hline & 6 & 82,18 & 5,60 & 12,22 & $\begin{array}{l}\text { Pasir } \\
\text { Berlempung }\end{array}$ & 1,25 & $\mathrm{R}$ \\
\hline
\end{tabular}

Keterangan: BOT= Bahan Organik Total; $\mathrm{S}=$ Sedang; R=Rendah; $\mathrm{SR}=$ Sangat Rendah

Penentuan kriteria kandungan bahan organik adalah apabila nilai $<1 \%$ merupakan kategori sangat rendah, nilai $1-2 \%$ rendah, 2-3 \% sedang, 3-5 \% tinggi, dan $>5 \%$ sangat tinggi (Soepardi, 1983).

Fraksi substrat mangrove di Pantai Karang Sewu dominan mengandung pasir. Persentase fraksi pasir tertinggi ditemukan pada Stasiun 1 plot 1 yaitu $88,71 \%$ sedangkan fraksi pasir terendah ditemukan pada Stasiun 1 plot 2 yaitu 21,54\%. Jika dilihat dari tekstur substrat, pasir berlempung mendominasi seluruh stasiun, sedangkan tekstur lempung berpasir hanya ditemukan di empat plot dan tekstur pasir, lempung berdebu dan lempung liat berpasir masing-masing hanya ditemukan pada satu plot. Adanya perbedaan persebaran tekstur substrat pada masingmasing stasiun dapat dipengaruhi oleh perbedaan kerapatan vegetasi mangrove. Semakin tinggi kerapatan vegetasi mangrove, maka serasah yang dihasilkan akan lebih tinggi dan kemampuan akar mangrove untuk mengikat substrat semakin kuat (Aini et al., 2016).

Hal ini sejalan dengan penelitian yang dilakukan oleh Marbawa (2012), dimana vegetasi mangrove di Pantai Karang Sewu memiliki tingkat regenerasi yang kurang baik. Lokasi ini memperlihatkan semakin kecil pertumbuhannya, kerapatannya semakin tinggi, namun pada tingkat pohon banyak yang mati karena kompetisi antar vegetasi, sehingga menyebabkan kerapatan vegetasi tingkat pohon termasuk kedalam kategori jarang. Kondisi tersebut menyebabkan substrat didominasi oleh fraksi pasir dikarenakan produksi serasah mangrove yang rendah. Pengaruh arus juga sangat berperan bagi distribusi fraksi substrat, karena lokasi Pantai Karang Sewu berdekatan dengan Selat Bali. Setiady et al (2010) menyatakan fraksi pasir yang dibawa oleh arus Selat Bali lebih mendominasi dibandingkan fraksi lempung yang sangat jarang dijumpai.

Kandungan bahan organik tertinggi ditemukan pada Stasiun 1 plot 2 dengan persentase 2,44\%, sedangkan kandungan bahan organik terendah dengan persentase $0,79 \%$ ditemukan pada Stasiun 1 plot 6, Stasiun 3 plot 1 dan Stasiun 3 plot 3. Kandungan bahan organik di Pantai Karang Sewu yang cenderung dalam kategori sedang hingga sangat rendah dapat disebabkan oleh nilai $\mathrm{pH}$ yang cenderung asam, sehingga aktivitas dekomposer menjadi rendah (Poedjirahajoe et al., 2017). Kondisi ini juga terjadi karena terserapnya bahan organik oleh akar mangrove untuk pertumbuhan. Bahan organik pada Stasiun 1 plot 2 lebih tinggi mungkin dikarenakan tekstur substrat cenderung berlempung dan fraksi pasir yang rendah, sehingga dapat menghasilkan bahan organik yang lebih tinggi karena proses dekomposisi pada plot ini lebih tinggi dibandingkan plot lainnya (Darmadi et al., 2012).

\subsection{Struktur Vegetasi Mangrove}

Terdapat sembilan spesies mangrove dari tiga stasiun di Pantai Karang Sewu yakni Ceriops tagal, Sonneratia alba, S. caseolaris, Rhizophora apiculata, $R$. mucronata, $R$. stylosa, R. lamarckii, Lumnitzera racemosa dan Avicennia marina (Tabel 3).

Tabel 3. Komposisi Vegetasi Mangrove

\begin{tabular}{|c|c|c|c|c|c|c|c|c|c|c|c|c|c|c|c|c|c|c|}
\hline \multirow{2}{*}{ Spesies } & \multicolumn{6}{|c|}{ Stasiun 1} & \multicolumn{6}{|c|}{ Stasiun 2} & \multicolumn{6}{|c|}{ Stasiun 3} \\
\hline & 1 & 2 & 3 & 4 & 5 & 6 & 1 & 2 & 3 & 4 & 5 & 6 & 1 & 2 & 3 & 4 & 5 & 6 \\
\hline C. tagal & - & - & & $\sqrt{ }$ & & $\sqrt{ }$ & & $\sqrt{ }$ & & & & $\sqrt{ }$ & $\sqrt{ }$ & & $\sqrt{ }$ & $\sqrt{ }$ & - & $\sqrt{ }$ \\
\hline S. alba & $\sqrt{ }$ & $\sqrt{ }$ & $\sqrt{ }$ & - & - & - & 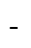 & - & 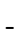 & & & & - & & - & - & - & \\
\hline S. caseolaris & $\sqrt{ }$ & $\sqrt{ }$ & $\sqrt{ }$ & - & - & - & - & - & - & - & - & - & - & & - & - & - & 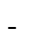 \\
\hline R. apiculata & $\sqrt{ }$ & $\sqrt{ }$ & $\sqrt{ }$ & $\sqrt{ }$ & $\sqrt{ }$ & $\sqrt{ }$ & - & - & - & - & - & - & - & & - & $\sqrt{ }$ & $\sqrt{ }$ & $\sqrt{ }$ \\
\hline $\begin{array}{l}R . \\
\text { mucronata }\end{array}$ & - & - & & - & - & - & & - & - & & & & - & & - & - & - & - \\
\hline R. stylosa & - & - & - & - & - & - & $v$ & - & - & - & - & - & - & - & - & - & - & - \\
\hline R. lamarckii & - & - & - & - & - & - & $\sqrt{v}$ & - & - & $\sqrt{ }$ & - & - & - & - & - & - & - & - \\
\hline L. racemose & - & - & - & - & - & - & - & - & - & - & - & - & $\sqrt{ }$ & & $\sqrt{ }$ & - & - & - \\
\hline A. marina & - & - & - & - & - & - & - & - & - & - & - & - & - & - & - & $\sqrt{ }$ & $\sqrt{ }$ & $\sqrt{ }$ \\
\hline
\end{tabular}

Spesies mangrove yang ditemukan di Pantai Karang Sewu secara keseluruhan merupakan jenis mangrove sejati. Wiyanto dan Faiqoh (2015) menemukan sebelas spesies mangrove di Teluk Benoa yakni $S$. alba, $S$. caseolaris, $R$. mucronata, $R$. stylosa, $R$. apiculata, X. granatum, B. gymnorrhiza, B. cylindrica, A. officinalis, A. marina dan $C$. tagal. Sedangkan spesies mangrove yang terdapat di Perancak, Kabupaten Jembrana sebanyak delapan spesies yakni A. alba, A. marina, R. apiculata, $R$. mucronata, S. alba, B. gymnorrhiza, C. tagal dan X. granatum (Suryono et al., 2018).

\subsubsection{Kerapatan Relatif Vegetasi}

Kerapatan relatif vegetasi mangrove tertinggi pada Stasiun 1 adalah spesies $R$. apiculata untuk tingkat pohon $(54,55 \%)$, tiang $(65,43 \%)$, pancang $(44,84 \%)$ dan semai $(62,16 \%)$. Kerapatan relatif tertinggi pada Stasiun 2 untuk tingkat pohon adalah spesies 
R. lamarckii $(85,71 \%)$ dan C. tagal memiliki kerapatan tertinggi pada tingkat tiang $(74,29 \%)$, pancang $(97,32 \%)$ dan semai $(97,22 \%)$. Kerapatan relatif tingkat pohon pada Stasiun 3 adalah $0 \%$ karena vegetasi tingkat pohon tidak ditemukan, sedangkan kerapatan relatif tingkat tiang tertinggi yakni $R$. apiculata $(32,65$ $\%$ ) dan $C$. tagal memiliki kerapatan tertinggi untuk tingkat pancang $(29,81 \%)$ dan semai $(53,85 \%)$ (Gambar 2).

Kerapatan relatif vegetasi mangrove di Pantai Karang Sewu didominasi oleh genus Rhizophora dan Ceriops, dimana keduanya merupakan famili Rhizophoraceae yang mampu beradaptasi dengan baik pada kondisi lingkungan yang tidak stabil (Hidayatullah dan Pujiono, 2014). Sejalan dengan hal tersebut, dapat dilihat bahwa dengan kondisi suhu tinggi dan $\mathrm{pH}$ yang cenderung asam di Pantai Karang Sewu, $R$. apiculata, $R$. lamarckii dan $C$. tagal dapat tumbuh dengan baik dan memiliki kerapatan yang tinggi dibandingkan dengan spesies lainnya.

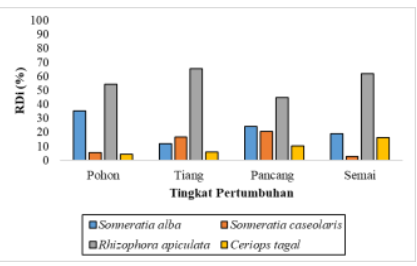

(a)

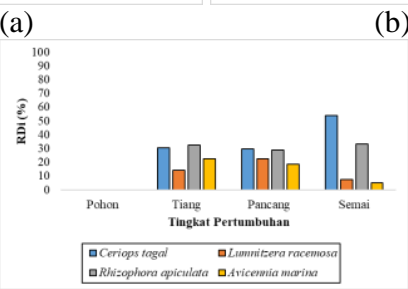

(c)

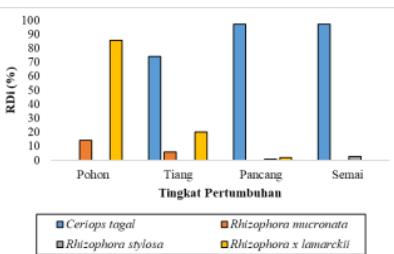

(b)
Gambar 2. Kerapatan Relatif Vegetasi Mangrove pada masingmasing stasiun.

(a) Stasiun 1; (b) Stasiun 2; (c) Stasiun 3

\subsubsection{Frekuensi Relatif Vegetasi}

Frekuensi relatif vegetasi mangrove tertinggi pada Stasiun 1 adalah spesies $R$. apiculata untuk tingkat pohon $(45,45 \%)$, tiang $(42,86 \%)$, pancang $(46,15 \%)$ dan semai $(49,32 \%)$. Frekuensi relatif pada Stasiun 2 untuk tingkat pohon, spesies $R$. mucronata dan $R$. lamarckii memiliki nilai yang sama yakni $50 \%$, sedangkan C. tagal memiliki nilai tertinggi untuk tingkat tiang (75\%), pancang $(50 \%)$ dan semai $(85,71 \%)$. Frekuensi relatif tingkat pohon pada Stasiun 3 adalah $0 \%$ karena vegetasi tingkat pohon tidak ditemukan, sedangkan spesies $C$. tagal memiliki nilai frekuensi relatif tertinggi untuk tingkat tiang $(41,67 \%)$, pancang $(38,46 \%)$ dan semai $(41,67 \%)$ (Gambar 3).

Dilihat dari intensitas ditemukannya spesies mangrove pada tiga stasiun, $C$. tagal memiliki tingkat distribusi yang tinggi, dimana spesies ini dapat ditemukan di seluruh stasiun baik pada tingkat semai, pancang, tiang dan pohon. Hal ini dikarenakan spesies ini memiliki sifat tumbuh berkelompok dan sporadis (persebaran tidak menentu) pada kawasan hutan mangrove (Marbawa et al., 2012).

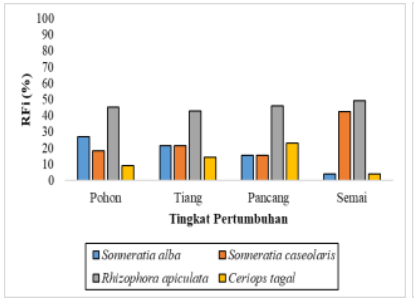

(a)

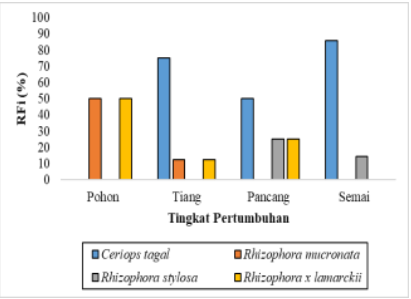

(b)

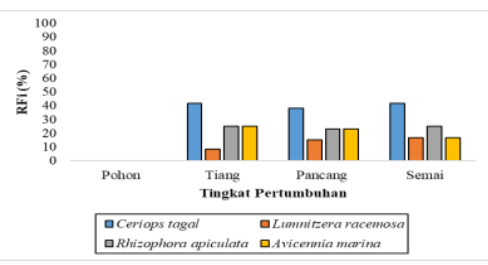

(c)

Gambar 3. Frekuensi Relatif Vegetasi Mangrove pada masingmasing stasiun.

(a) Stasiun 1; (b) Stasiun 2; (c) Stasiun 3

\subsubsection{Dominansi Relatif Vegetasi}

Dominansi relatif vegetasi mangrove tertinggi pada Stasiun 1 adalah spesies $R$. apiculata untuk tingkat pohon $(52,88 \%)$, tiang $(65,95 \%)$ dan pancang $(48,04 \%)$. Dominansi relatif tertinggi di Stasiun 2 untuk tingkat pohon adalah $R$. lamarckii $(91,23 \%)$, sedangkan $C$. tagal memiliki nilai tertinggi untuk tingkat tiang $(71,54 \%)$ dan pancang $(96,33 \%)$. Dominansi relatif tingkat pohon pada Stasiun 3 adalah $0 \%$ karena vegetasi tingkat pohon tidak ditemukan, sedangkan $C$. tagal memiliki nilai dominansi relatif tertinggi untuk tingkat tiang yakni 31,40\% dan tingkat pancang dominansi relatif tertinggi adalah spesies $R$. apiculata dengan nilai 32,79 \% (Gambar 4). Hal ini membuktikan bahwa spesies pada masing-masing stasiun yang memiliki nilai dominansi tertinggi memiliki kelimpahan yang lebih banyak dan penguasaan lahan yang lebih luas (Warsidi dan Endayani, 2017).

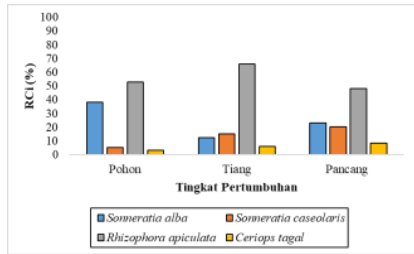

(a)

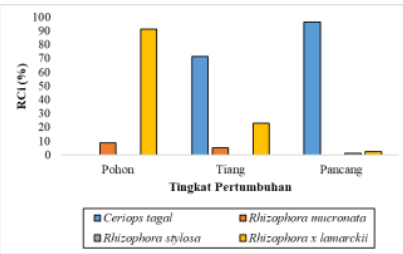

(b)

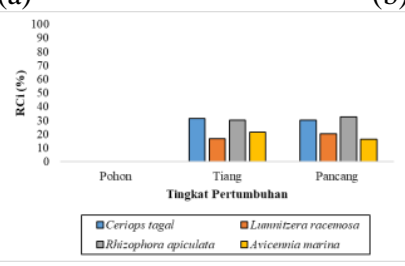

(c)

Gambar 4. Dominansi Relatif Vegetasi Mangrove pada masingmasing stasiun.

(a) Stasiun 1; (b) Stasiun 2; (c) Stasiun 3

\subsubsection{Indeks Nilai Penting (INP)}

\section{a. Stasiun 1}

Hasil Indeks Nilai Penting (INP) diperoleh dari menjumlahkan nilai kerapatan relatif $(\mathrm{Kr})$, frekuensi relatif (Fr) dan Dominansi relatif (Dr). INP pada Stasiun 1 didominasi oleh spesies $R$. apiculata untuk tingkat pohon $(152,88 \%)$, tiang $(174,24 \%)$, pancang $(139,04)$ dan semai $(111,48 \%)$, sedangkan INP terendah adalah spesies $C$. tagal pada tingkat pohon $(17,14 \%)$, tiang $(26,55 \%)$, pancang $(41,82 \%)$ dan semai $(20,33 \%)$ (Gambar 5$)$. Berdasarkan hasil tersebut, terlihat bahwa pola distribusi INP di Stasiun 1 didominasi oleh satu spesies yakni $R$. apiculata sedangkan INP spesies lainnya sangat rendah. Walau demikian, terlihat bahwa keempat spesies tersebut memiliki tingkat regenerasi yang baik, karena ditemukan pada seluruh tingkat pertumbuhan.

Spesies $R$. apiculata dapat mendominasi dikarenakan faktor lingkungan yang sangat sesuai. Tekstur substrat di Stasiun 1 banyak terdapat pasir berlempung yang cocok untuk perakaran 
spesies ini dan memiliki kandungan bahan organik tertinggi dibandingkan stasiun lainnya yaitu $2,44 \%$, sehingga sangat menunjang spesies ini untuk tumbuh dan berkembang. Hal yang sama ditemukan di Desa Cangkring, Kabupaten Indramayu, dimana INP untuk tingkat pancang dan pohon didominasi oleh $R$. apiculata (Darmadi et al., 2012). R. apiculata di Teluk Benoa memiliki INP 92,26\% untuk tingkat pohon dan 82,89\% untuk tingkat anakan (Wiyanto dan Faiqoh, 2015).

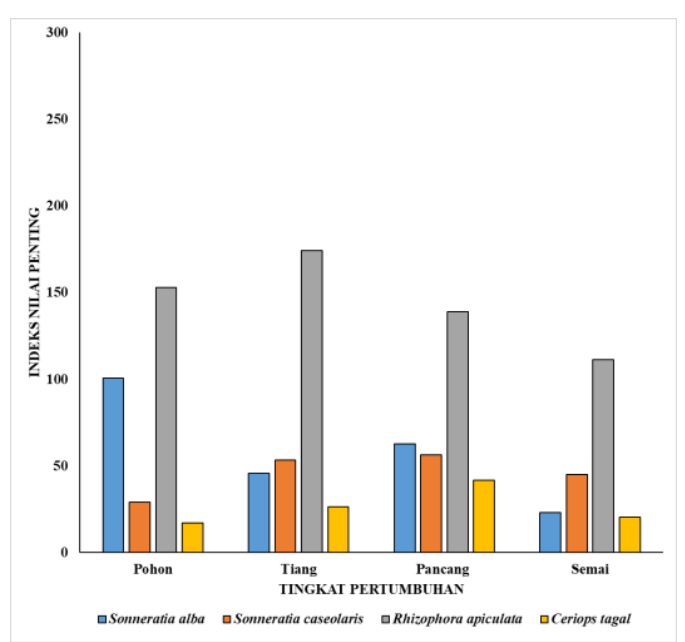

Gambar 5. Indeks Nilai Penting Stasiun 1

\section{b. Stasiun 2}

Indeks Nilai Penting pada Stasiun 2 untuk tingkat pohon didominasi oleh spesies $R$. lamarckii dengan nilai INP 226,94\% sedangkan $R$. mucronata memiliki nilai INP lebih rendah yakni 73,06 \%. Tingkat tiang di dominasi oleh $C$. tagal dengan nilai INP 220,82 \% sedangkan $R$. mucronata memiliki nilai INP terendah yakni $23,6 \%$. Untuk tingkat pancang dan semai, $C$. tagal memiliki nilai INP tertinggi yakni $243,65 \%$ untuk tingkat pancang dan 182,94\% untuk tingkat semai sedangkan spesies $R$. stylosa memiliki nilai INP terendah yakni 26,99\% untuk tingkat pancang dan 17,06 \% untuk tingkat semai (Gambar 6). Spesies yang mendominasi di stasiun ini merupakan famili Rhizophoraceae, dimana menurut Bengen (2010) famili ini sangat umum dijumpai dan mendominasi kawasan hutan mangrove di Indonesia.

Hal yang sama ditemukan di Desa Golo Sepang Kecamatan Boleng Kabupaten Manggarai Barat, dimana genus Rhizophora dan Ceriops yang termasuk famili Rhizophoraceae mendominasi kawasan ini karena sangat baik dalam memanfaatakan unsur hara atau mineral dan energi matahari sehingga mampu berkompetisi dengan baik dan mendomniasi dibandingkan spesies lainnya (Hidayatullah dan Pujiono, 2014). Alwidakdo et al. (2014) menyatakan bahwa kondisi lingkungan yang sesuai dapat menunjang pertumbuhan Rhizophora sp. dan Ceriops sp. Kondisi lingkungan pada Stasiun 2 menunjukkan suhu air rata-rata $28,4{ }^{\circ} \mathrm{C}$ dan suhu substrat rata-rata $28,6{ }^{\circ} \mathrm{C}$, sehingga suhu pada Stasiun 2 sangat menunjang pertumbuhan spesies tersebut.

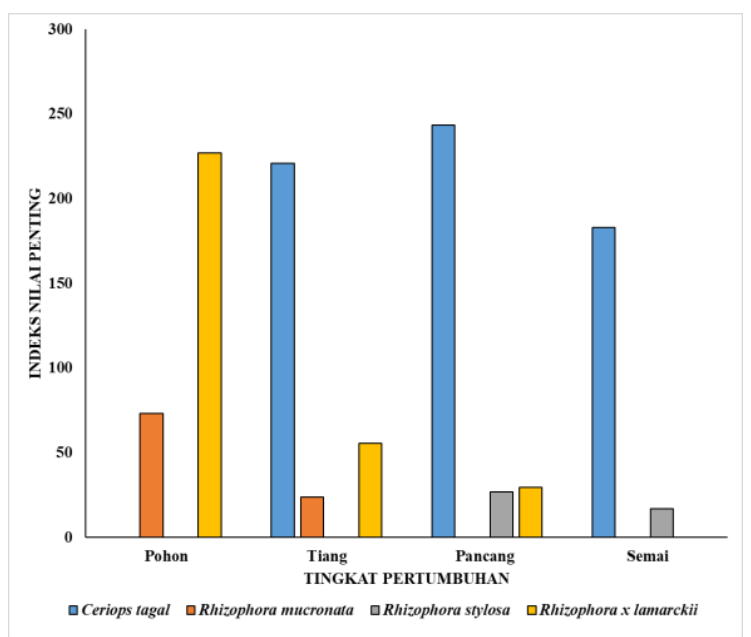

Gambar 6. Indeks Nilai Penting Stasiun 2

\section{c. Stasiun 3}

Indeks Nilai Penting pada Stasiun 3 untuk tingkat pohon tidak ditemukan. Spesies $C$. tagal mendominasi untuk tingkat tiang $(103,68 \%)$, pancang $(98,77 \%)$ dan semai $(95,51 \%)$. INP terendah pada tingkat tiang terdapat pada spesies Limnitzera racemose dengan nilai INP 39,29\%, sedangkan spesies $A$. marina memiliki nilai terendah untuk tingkat pancang $(57,88 \%)$ dan semai $(21,79 \%$ ) (Gambar 7). Berdasarkan hasil tersebut spesies C. tagal mendominasi pada Stasiun 3 serta tingkat regenerasi keempat spesies tersebut kurang baik, karena tidak ditemukannya vegetasi tingkat pohon. Spesies $C$. tagal mendominasi pada Stasiun 3 dikarenakan pada stasiun ini memiliki kandungan $\mathrm{pH}$ air dan substrat yang cenderung netral yakni 6,9 dapat menunjang pertumbuhan spesies ini serta tekstur substrat yang didominasi oleh pasir berlempung sesuai untuk $C$. tagal yang memiliki akar lutut.

Hasil tersebut didukung oleh penelitian Marbawa et al (2012) dimana $C$. tagal mendominasi komunitas mangrove di Taman Nasional Bali Barat khususnya di Pantai Karang Sewu dan diperkirakan akan terus mendominasi dimasa yang akan datang. Hal ini dikarenakan benih spesies ini sudah mampu tumbuh (propagul) pada saat masih berada di tumbuhan induk, sehingga dapat menunjang proses distribusi yang luas pada ekosistem mangrove (Bengen, 2010).

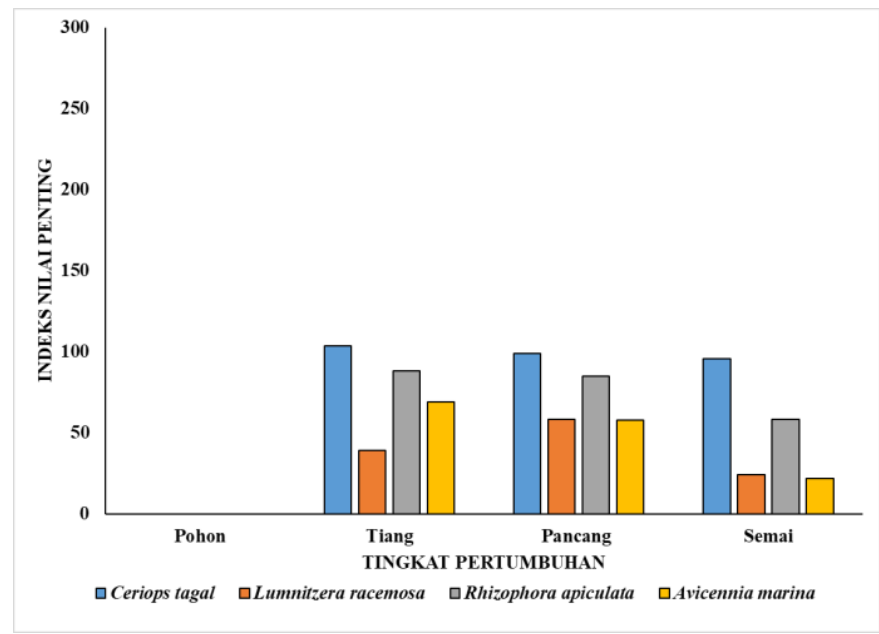

Gambar 7. Indeks Nilai Penting Stasiun 3 


\subsection{Pengelompokkan Vegetasi Mangrove Berdasarkan Karakteristik Substrat}

Karakteristik substrat pada ekosistem mangrove diketahui dapat menentukan kehidupan vegetasi mangrove itu sendiri Berdasarkan hasil analisis struktur vegetasi mangrove dan analisis karakteristik substrat, didapatkan hasil bahwa tiap spesies mangrove tumbuh pada tekstur substrat dan kandungan bahan organik yang berbeda-beda, selanjutnya dapat dilihat pada Tabel 5.

Tabel 5. Komposisi Vegetasi Mangrove

\begin{tabular}{lcccccc}
\hline \multirow{2}{*}{ Spesies } & \multicolumn{5}{c}{ Tekstur Substrat } & \multirow{2}{*}{ BOT } \\
\cline { 2 - 6 } & P & LBd & LBp & PB & LLB & \\
\hline C. tagal & - & - & $\sqrt{ }$ & $\sqrt{ }$ & $\sqrt{ }$ & S-SR \\
S. alba & $\sqrt{ }$ & $\sqrt{ }$ & $\sqrt{ }$ & - & - & $\mathrm{S}$ \\
S. caseolaris & $\sqrt{ }$ & $\sqrt{ }$ & $\sqrt{ }$ & - & - & $\mathrm{S}$ \\
R. apiculata & $\sqrt{ }$ & $\sqrt{ }$ & $\sqrt{ }$ & $\sqrt{ }$ & - & $\mathrm{S}-\mathrm{SR}$ \\
R. mucronata & - & - & - & $\sqrt{ }$ & - & $\mathrm{R}$ \\
R. stylosa & - & - & - & $\sqrt{ }$ & - & $\mathrm{R}$ \\
R. lamarckii & - & - & - & $\sqrt{ }$ & - & $\mathrm{R}$ \\
A. marina & - & - & - & $\sqrt{ }$ & - & $\mathrm{R}$ \\
L. racemose & - & - & $\sqrt{ }$ & - & - & $\mathrm{SR}$
\end{tabular}

Keterangan: $\mathrm{P}=$ Pasir; $\mathrm{LBd}=$ Lempung Berdebu; $\mathrm{LBp}=$ Lempung Berpasir; LLB = Lempung Liat Berpasir; BOT = Bahan Organik Total; $\mathrm{S}$ = Sedang; $\mathrm{R}=$ Rendah; $\mathrm{SR}=$ Sangat Rendah.

Tabel 5 menunjukkan bahwa spesies $C$. tagal ditemukan pada zona tengah hingga zona belakang dengan tekstur substrat lempung berpasir, pasir berlempung, dan lempung liat berpasir. Hal ini sangat sesuai bagi akar lutut yang dimiliki oleh $C$. tagal, karena mampu mengikat substrat berlempung. Spesies ini memiliki kemampuan yang sangat baik dalam memanfaatkan unsur hara atau mineral, walaupun dengan kondisi bahan organik yang sedang hingga sangat rendah (Lewerissa et al., 2018).

Spesies $S$. alba dan $S$. caseolaris tumbuh pada substrat bertekstur pasir, lempung berdebu dan lempung berpasir (Gambar 8). Hal ini sesuai dengan pernyataan Indah et al (2010) bahwa tekstur substrat yang cenderung berpasir sangat cocok untuk pertumbuhan Sonneratia. spp. Spesies ini tumbuh pada zona terdepan serta memiliki akar napas yang mampu bertahan pada substrat berpasir dan beradaptasi saat terendam air laut. Bahan organik yang termasuk kategori sedang juga dapat menunjang pertumbuhan $S$. alba dan $S$. caseolaris.

Spesies $R$. apiculata ditemukan pada zona terdepan hingga zona tengah dengan substrat pasir, lempung berdebu, lempung berpasir dan pasir berlempung. $R$. mucronata, $R$. stylosa dan $R$. lamarckii tumbuh pada zona tengah dengan substrat pasir berlempung dengan kandungan bahan organik yang rendah (Gambar 8). Kondisi ini sesuai dengan hasil penelitian yang dilakukan oleh Purwanti (2013) yaitu Rhizopora sp. lebih banyak ditemukan pada substrat yang cenderung berlempung karena memiliki akar tunjang yang mampu menopang tubuh tumbuhan dan mampu beradaptasi pada kondisi lingkungan yang tidak stabil. Berbeda halnya dengan spesies $R$. apiculata yang ditemukan pada zona terdepan dan tumbuh pada substrat berpasir. Hal ini dapat disebabkan oleh kesesuaian faktor lingkungan yang menunjang pertumbuhan, dimana spesies ini banyak ditemukan pada Stasiun 1 yang mengandung bahan organik sedang. Kondisi yang sama ditemukan di Desa Cangkring, Indramayu dimana $R$. apiculata ditemukan tumbuh dengnan baik pada zona yang berhadapan langsung dengan laut (zona terdepan) (Darmadi et al., 2012).

Spesies A. marina tumbuh pada zona tengah dengan substrat bertekstur pasir berlempung (Gambar 8). Persebaran spesies ini berbeda pada umumnya. Menurut Yuvuraj et al (2017), spesies ini biasanya ditemukan pada zona yang dekat dengan laut (zona terdepan) dan tumbuh pada substrat berpasir, namun di Pantai Karang Sewu ditemukan pada zona tengah. Kondisi ini terjadi karena kandungan salinitas dari zona terdepan hingga zona ditemukannya $A$. marina tidak berbeda secara signifikan, sehingga spesies ini mampu tumbuh pada zona tengah (Khairijon et al., 2015).

Spesies L. racemosa tumbuh pada substrat lempung berpasir dan ditemukan pada zona yang dekat dengan daratan (zona belakang) (Gambar 8). Spesies ini tumbuh pada substrat dengan kandungan bahan organik yang sangat rendah. Hal ini sesuai dengan pernyataan (Yuvuraj et al., 2017), bahwa L. racemosa sering dijumpai pada zona belakang dan tumbuh pada substrat berlempung padat. Kondisi tersebut dikarenakan $L$. racemosa hidup pada kawasan yang jarang terkena pengaruh pasang surut, sehingga regenerasi hanya terjadi pada zona belakang (Raju et al., 2014).

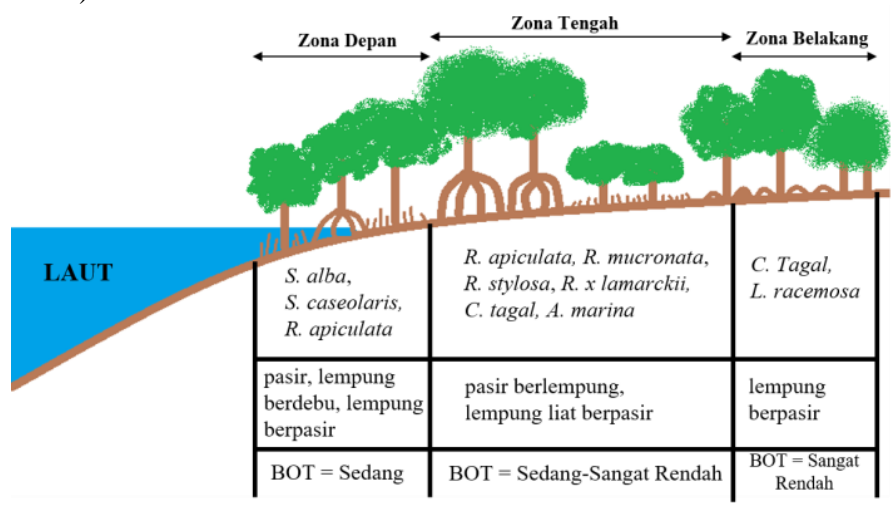

Gambar 8. Pengelompokkan vegetasi mangrove berdasarkan karakteristik substrat

\section{Kesimpulan}

Kesimpulan yang didapatkan dari penelitian ini yaitu:

1. Struktur vegetasi mangrove di Pantai Karang Sewu secara keseluruhan terdiri dari sembilan spesies mangrove yang seluruhnya merupakan mangrove sejati. Nilai kerapatan relatif berkisar 29,81 - 97,32 \%, frekuensi relatif 38,46$85,71 \%$ dan dominansi relatif $31,40-96,33 \%$. Indeks Nilai Penting tingkat semai berkisar 17,06 - 182,94 \%, tingkat pancang 26,99 - 243,65\%, tingkat tiang 23,6 - 220,82 \% dan tingkat pohon $17,14-226,94 \%$.

2. Karakteristik substrat mangrove di Pantai Karang Sewu memiliki lima tipe tekstur yaitu pasir, lempung berdebu, lempung berpasir, pasir berlempung dan lempung liat berpasir yang dominan mengandung fraksi pasir. Kandungan bahan organik total termasuk kategori sedang $(2,44 \%)$ hingga sangat rendah $(0,79 \%)$.

3. Pengelompokan vegetasi mangrove berdasarkan karakteristik substrat di Pantai Karang Sewu berbeda pada umumnya. Spesies $S$. alba, S. caseolaris dan $R$. apiculata ditemukan pada zona depan, tumbuh pada substrat pasir, lempung berdebu dan lempung berpasir dengan kandungan bahan organik sedang. Spesies $C$. tagal, $R$. apiculata, $R$. mucronata, $R$. stylosa, $R$. lamarckii dan A. marina ditemukan pada zona tengah, tumbuh pada substrat pasir berlempung dengan kandungan bahan organik rendah. Spesies $C$. tagal dan $L$. racemosa ditemukan pada zona belakang, tumbuh pada 
substrat lempung berpasir dengan kandungan bahan organik sangat rendah.

\section{Ucapan Terima kasih}

Penulis mengucapkan terima kasih kepada Balai Taman Nasional Bali Barat yang telah memberikan izin untuk melakukan penelitian di Pantai Karang Sewu, serta memberikan masukan dan saran selama penelitian berlangsung.

\section{Daftar Pustaka}

Aini HR, Suryanto A, Hendrarto B. 2016. Hubungan Tekstur Sedimen dengan Mangrove di Desa Mojo Kecamatan Ulujami Kabupaten Pemalang. Diponegoro Journal of Maquares. Vol. 5(4): 209-215

Allen SE, Grimshaw HM, Parkinson A, Quarmby C. 1974. Analysis of Soil in Chemical Analysis of Ecological Materials. Blackwell Scientific Publication, Oxford. $565 \mathrm{hlm}$

Alwidakdo A, Azham Z, Kamarubayana L. 2014. Studi Pertumbuhan Mangrove pada Kegiatan Rehabilitasi Hutan Mangrove di Desa Tanjung Limau Kecamatan Muara Badak Kabupaten Kutai Kartanegara. Jurnal Agrifor. Vol 13(1): 11-18

Basyuni M. 2014. Panduan Restorasi Hutan Mangrove yang Rusak (Degrated). USU Digital Library. $13 \mathrm{hlm}$

Bengen DG. 2010. Ekosistem dan Sumberdaya Alam Pesisir dan Laut serta Prinsip Pengelolaannya Secara Terpadu dan Berkelanjutan. Prosiding Pelatihan Pengelolaan Wilayah Pesisir Terpadu: Bogor, 24 Mei 2010. Institut Pertanian Bogor. hlm 37

Darmadi, Lewaru MW, Khan AMA. 2012. Struktur Komunitas Vegetasi Mangrove Berdasarkan Karakteristik Substrat di Muara Harmin Desa Cangkring Kecamatan Tan Cantigi Kabupaten Indramayu. Jurnal Perikanan dan Kelautan Unpad. Vol. 3(3): 347-358

Davies J, Claridge G. 1993. Wetland Benefits: The Potential for Wetlands to Support and Maintain Development. Asian Wetland Bureau, International Waterfowl \& Wetlands Research Bureau, Wetlands for the America's. hlm. 1-45

Hambaran, Linda R, Lovadi I. 2014. Analisa Vegetasi Mangrove di Desa Sebubus Kecamatan Paloh Kabupaten Sambas. Protobiont. Vol 3(2): 201 208

Heiri, O., A. F. Lotter, and G. Lemcke. 2001. Loss on Ignation as A Method for Estimating Organic and Carbonate Content in Sediments: Reproducibility and Comparability of Results. Journal of Paleolimnology. Vol 25: $101-110$

Hidayatullah M, Pujiono E. 2014. Struktur dan Komposisi Jenis Hutan Mangrove di Golo Sepang Kecamatan Boleng Kabupaten Manggarai Barat. Jurnal Penelitian Kehutanan Wallacea. Vol. 3(2): 151-162

Indah R, Jabarsyah A, Laga A. 2010. Perbedaan Substrat Dan Distribusi Jenis Mangrove (Studi Kasus: Hutan Mangrove di Kota Tarakan). Jurnal Harpodon Borneo. Vol. 3(1): 66-84

Khairijon, Sofiyanti N, Fadli. 2015. Korelasi Antara Kerapatan A. dengan Karakteristik Sedimen di Kawasan Hutan Mangrove Desa Sungai Rawa Kabupaten Siak, Riau. Prosiding Semirata 2015 bidang MIPA BKS-PTN Barat. Pontianak: Universitas Tanjungpura. hlm 300-309

Kolinug KH, Langi MA, Ratag SP, Nurmawan W. 2014. Zonasi Tumbuhan Utama Penyusun Mangrove Berdasarkan Tingkat Salinitas Air Laut di Desa Teling Kecamatan Tombariri. COCOS. Vol 5(4): 1-9

Kusmana C, et al. 2003. Teknik Rehabilitasi Mangrove. Fakultas Kehutanan Institut Pertanian Bogor. $181 \mathrm{hlm}$

Kusmana C. 2017. Metode survey dan Interpretasi Data Vegetasi. IPB Press. $68 \mathrm{hlm}$

Lanuru M, Suwarni. 2011. Pengantar Oseanografi. Bahan Ajar. Makassar, Indonesia. Fakultas Ilmu Kelautan dan Perikanan Universitas Hassanuddin

Lestaru A, Saru A, Lanuru M. 2018. Konsentrasi Bahan Organik dalam Sedimen Dasar Perairan Kaitannya dengan Kerapatan dan Penutupan Jenis Mangrove di Pulau Pannikiang Kecamatan Balusu Kabupaten Barru. Prosiding Simposium Nasional Kelautan dan Perikanan V;
Universitas Hassanudin, 5 Mei 2018. Makassar: SIMNAS KP UNHAS. hlm 29

Lewerissa YA, Sangaji M, Latumahina MB. 2018. Pengelolaan Mangrove Berdasarkan Tipe Substrat di Perairan Negeri Ihamahu Pulau Saparua. Jurnal TRITON. Vol. 14(1): 1-9

Marbawa IKC, Astarini IA, Mahardika IG. 2012. Analisis Vegetasi Mangrove untuk Strategi Pengelolaan Ekosistem Berkelanjutan di Taman Nasional Bali Barat. ECOTROPHIC. Vol. 8(1): 24-38

Martuti NKT. 2013. Keanekaragaman Mangrove di Wilayah Tapak, Tugurejo, Semarang. Jurnal MIPA. Vol 36(2): 123-130

[MNLH] Menteri Negara Lingkungan Hidup. 2004. Baku Mutu Air Laut. Nomor 51 Tahun 2004. Jakarta

Mullet EKC, et al. 2014. Assesment of Mangrove Species and its Relation to Soil Substrat in Malapatan, Sarangani Province, Philippines. Journal of Biodiversity and Environmental Sciences (JBES). Vol. 5(4): 100-107

Murray BC. 2011. State of the Science on Coastal Blue Carbon: A Summary for Policy Makers. Nicholas Institute for Environmental Policy Solutions. $43 \mathrm{hlm}$

Pendleton L, et al. 2012. Estimating Global "Blue Carbon" Emissions from Conversion and Degradation of Vegetated Coastal Ecosistems. PLoS ONE. Vol. 7(9): 1-7

Poedjirahajoe E, Marsono D, Wardhani FK. 2017. Penggunaan Principal Component Analysis dalam Distribusi Spasial Vegetasi Mangrove di Pantai Utara Pemalang. Jurnal Ilmu Kehutanan. Vol 11: 29-42

Puja, I. N. (2016). Penuntun Praktikum Fisika Tanah. Panduan Pelaksanaan Praktikum. Denpasar, Indonesia: Fakultas Pertanian Universitas Udayana.

Raju AJS, Kumar R, Rajesh B. 2014. Pollination Ecology of L. Racemosa Willd. (Combretaceae), a Non-Viviparous Mangrove Tree. TAPROBANICA. Vol. 6(2): 100-109

Saenger PEJ, Hegerl, Da Vie JDS. 1983. Global status of mangrove ecosistems. By the working group on mangrove ecosistems on the IUCN Commission on Ecology. The environmentalist. Vol. 3: 88

Santosa H. 2018. Ekosistem Mangrove di Taman Nasional Bali Barat. Balai Taman Nasional Bali Barat. 201 hlm

Saru A, Amri K, Mardi. 2017. Konektivitas Struktur Vegetasi Mangrove dengan Keasaman dan Bahan Organik Total pada Sedimen di Kecamatan Wonomulyo Kabupaten Polewali Mandar. SPERMONDE. Vol. 3(1): 1-6

Setiawan H. 2013. Status Ekologi Hutan Mangrove Pada Berbagai Tingkat Ketebalan. Jurnal Penelitian Kehutanan Wallacea. Vol. 2(2): 104-120

Soepardi G. 1983. Sifat dan Ciri Tanah. Jurusan Tanah Fakultas Pertanian Institut Pertanian Bogor. 591 hlm.

Soerianegara I. 1971. Characteristic of mangrove soil of Java. Rimba Indononesia. Vol.15: 141-150.

Suryono, Soenardji N, Wibowo E, Ario R, Rozy EF. 2018. Estimasi Kandungan Biomassa dan Karbon di Hutan Mangrove Perancak Kabupaten Jembrana, Provinsi Bali. Buletin Oseanografi Marina. Vol. $7(1): 1-8$

Susiana. 2015. Analisis Kualitas Air Ekosistem Mangrove di Estuari Perancak, Bali. Jurnal Ilmiah Agribisnis dan Perikanan. Vol. 8(1): 1-8

Ulqodry TZ, Bengen DG, Kaswadji RF. 2010. Karakteristik perairan mangrove Tanjung Api-api Sumatera Selatan berdasarkan sebaran parameter lingkungan perairan dengan menggunakan analisis komponen utama (PCA). MASPARI Journal. Vol 01: 16-21

Warsidi, Endayani S. 2017. Komposisi Vegetasi Mangrove Di Teluk Balikpapan Provinsi Kalimantan Timur. Jurnal AGRIFOR. Vol. 16(1): 115-124

Wentworth CK. 1922. A Scale of Grade and Class Terms for Clastic Sediments. The Journal of Geology. Vol. 30(5): 377-392

Wiyanto DB, Faiqoh E. 2015. Analisis Vegetasi dan Struktur Komunitas Mangrove di Teluk Benoa, Bali. Journal of Marine and Aquatic Sciences. Vol. 1: 1-7

Wijayanti T. 2009. Konservasi Hutan Mangrove Sebagai Wisata Pendidikan. Envirotek: Jurnal Ilmiah Teknik Lingkungan. Vol. 1: 15-25

Yuvaraj E, et al.2017. Distribution and zonation pattern of mangrove forest in Shoal Bay Creek, Andaman Islands, India. Indian Journal od Geo Marine Sciences. Vol. 46(3): 597-604

Zakaria LI. 2019. Kajian Karakteristik Kualitas Perairan dan Sedimen pada Ekosistem Mangrove di Wilayah Reklamasi Pulau Lumpur Sidoarjo [Skripsi]. Surabaya: Program Studi Ilmu Kelautan Fakultas Sains dan Teknologi Universitas Islam Negeri Sunan Ampel. hlm 4 